DOI

\title{
ДЕЯКІ АСПЕКТИ СУЧАСНОЇ ПЕДАГОГІКИ МЕДИЧНОЇ ОСВІТИ
}

\author{
А. В. Дерезюк
}

Вінницький національний медичний університет імені М. I. Пирогова

\section{SOME ASPECTS OF MODERN MEDICAL EDUCATION PEDAGOGY}

\section{A. V. Dereziuk}

\author{
Vinnytsia National Medical University by M. I. Pyrohov
}

\begin{abstract}
У статті узагальнено матеріали педагогічних видань 2012-2014 років. Основну увагу звернено на публікації учасників IX Міжнародної науково-методичної конференції “Духовна культура особистості та її інноваційні основні технології: виклики XXI століття”. Для дослідження обрано виступи викладачів вищих медичних навчальних закладів, у яких наголошено на таких аспектах педагогічної освіти, як: роль інноваційних засобів і технологій у процесі навчально-виховної роботи, психолого-педагогічна компетентність і мобільність майбутнього лікаря, вимоги до викладача сучасного вузу та ін.
\end{abstract}

The article presents the review of pedagogical publications of 2012-2014 years. The emphasis has been put on participants' publications of IX International scientific methodology conference "Spiritual culture of personality and its innovative technologies: challenges of XXI century”. The reports of teachers of higher medical institutions which cover the following aspects of pedagogical education: the role of innovative means and technologies in educational process; doctor's psychological and pedagogical competence and mobility; requirements to the modern university teacher and others have been selected for the investigation.

Вступ. Нова концепція розвитку вищої медичної освіти в Україні, що орієнтується на світові досягнення підготовки лікарів, передбачає корінні зміни якості освіти. Необхідність її реформування й удосконалення є однією з вимог на шляху до євроінтеграції. Рух до європейського освітнього простору передбачає ряд змін, що стосуються як навчальних предметів, так і методів їх викладання. Зростання актуальності якості медичної освіти пояснюється ще й тим, що вищі навчальні заклади отримали більше прав у виборі не лише методів, але й змісту освіти.

Не випадково реформування якості освіти й виховання у вищій школі на сучасному етапі стало об'єктом дослідження багатьох вчених-педагогів і викладачів-практиків.

Основна частина. За останні три роки (2012 2014) з'явилось чимало матеріалів, у тому числі й в періодичних виданнях педагогічного спрямування, в яких йдеться про підвищення якості освіти й виховання у вищій школі. Треба віддати належне Інституту інноваційних технологій і змісту освіти Міністерства освіти і науки України, Академії міжнародного співробітництва з креативної педагогіки, які протягом 2012 року видали серію об’ємних наукових збірників великого формату під загальною назвою “Нові технології навчання” для викладачів

\footnotetext{
(C) А. В. Дерезюк
}

і науковців. У збірниках вміщено кілька сотень наукових досліджень педагогів і практиків багатьох галузей знань, у тому числі й медичних, не лише 3 України, але й з інших країн. В основі їхніх публікацій - матеріали IX Міжнародної науково-методичної конференції “Духовна культура особистості та іiї інноваційні основні технології: виклики XXI століття”, організованої при сприянні Міністерства освіти і науки України Національною академією педагогічних наук та Академією міжнародного співробітництва з креативної педагогіки.

У дослідженнях, де йдеться про педагогіку вищої освіти, можна виділити кілька стержневих проблем. Однією із них є інноваційні засоби та мультимедійні технології навчання. Увага до них зростає повсякчас, адже аудіо- й відеотехніка сьогодні набули виняткового застосування.

Інновації - це новостворені чи удосконалені конкурентноспроможні технології, що істотно поліпшують якість навчання, підвищують результативність праці. “У медицині - це нові медичні технології (діагностика та профілактика захворювань, організація системи медичної допомоги та управління охороною здоров'я)”, - переконує житомирський викладач В. В. Свириднюк [5]. Аналогічну думку висловлює доцент С. В. Гордійчук у статті “Досвід підготовки кадрів для медсестринства”, у якій з'ясовано англійську й американську модель підготовки медичних кадрів [6]. 
За останні роки засоби навчання і виховання у навчальних закладах поповнилися пристроями, що діють на базі комп’ютерів і лазерів. Кіно й діапроекція поступово витісняються відеозаписами й мультимедійними проекторами. Саме найновіші технічні засоби сприяють забезпеченню повноти і точності інформації, покращують ефективність наочності, що, у свою чергу, підвищує інтерес студентів до виучуваного матеріалу, активізує їхню пізнавальну діяльність.

У ряді статей йде мова про ефективні методи освіти, що $є$ чи не головною метою вивчення педагогіки у вузі. Адже ще М. І. Пирогов свого часу зауважував: “Головне в навчанні не тільки те, що повідомляється, а й те, як повідомляється” [4].

Чимало уваги відведено формуванню основ психолого-педагогічної компетентності майбутнього лікаря, зокрема комунікативної компетентності здатності до ефективного спілкування, що особливо важливе, коли йдеться про хвору людину. Недаремно кажуть, що після розмови з хорошим лікарем хворому якщо й не стає легше, то хоча б спокійніше на душі. Навіть добре володіючи інноваційними методами навчання, використовуючи комп’ютер, мультимедійні засоби, Інтернет, викладач водночас послуговується словесними засобами (лекція, розповідь, бесіда, пояснення та ін.), що вимагають особливої комунікативної компетенції й таланту.

Варто звернути увагу й на мобільність у професійній підготовці фахівців. Адже сьогоднішній темп життя, кризовий стан економіки, перехід до ринкових умов її розвитку, суттєва зміна системи цінностей сучасного суспільства, стрімке оновлення технологій - в таких умовах фахівець повинен швидко адаптуватися до них. Тому “... проблема мобільності, зокрема мобільності професійної, і стає важливим аспектом вузівської підготовки” [6].

У багатьох статтях даються рекомендації щодо підготовки й читання лекцій, проведення практичних і семінарських занять, дискусій, рольових ігор та ін. Вчені-дидактики радять мати про запас кілька методик для досягнення навчальної мети. "Це дуже важливий аспект, оскільки не існує єдиного шляху для досягнення результату. Щось працює краще, щось гірше. Чим більше видів діяльності перебуває у розпорядженні викладача, тим більш невимушено він буде почувати себе за умови необхідності внесення коректив” [1].

Якість освіти значною мірою залежить від ії системності й неперервності. “Тільки система..., - - на думку геніального педагога К. Д. Ушинсього, - дає нам повну владу над нашими знаннями. Голова, на- повнена уривчастими, безладними знаннями, схожа на комору, в якій таке безладдя, що сам господар нічого не знайде" [4].

У ряді публікацій наголошено, що результативність освіти залежить не лише від того, хто вчиться, але й від того, хто вчить. До викладача сьогодні пред’являються особливі вимоги. Якщо раніше вважалося, що викладач вищої школи повинен мати широку ерудицію, досконало знати свій предмет, уміти захопити ним студентів, пам'ятаючи добре відомий у педагогіці вислів Паскаля про те, що “учень - це не посудина, яку необхідно наповнити, а факел, який потрібно запалити” [4]. Це, безперечно, так, але сьогодні цього мало. Досвідчений викладач зобов'язаний розвивати у студентів допитливість, уміння спостерігати різні явища, заглиблюватися в їхню суть, узагальнювати вивчене, ставити наукові експерименти, робити вірні висновки і навіть науково фантазувати. Для цього викладач сам повинен удосконалювати свою майстерність і педагогічне мислення. Великий педагог В. О. Сухомлинський наголошував: “Сильним, досвідченим стає той педагог, який уміє аналізувати свою працю” [4]. Педагог перестає бути взірцем для студента, якщо він не самоудосконалюється. “Учитель... може виховувати і навчати доти, допоки сам працює над своїм вихованням і освітою”, - застерігав К. Д. Ушинський [4].

Необхідною умовою якісної підготовки студентів $€$ розумна вимогливість викладача. Він не повинен пред’являти неадекватних вимог, що інколи ще й супроводжуються погрозами, пам'ятати, що, крім його предмета, студент повинен якісно засвоїти десятки інших навчальних дисциплін.

Яким би професіоналом не був викладач, якщо в час навчання не буде активної діяльності студентів, їх бажання засвоювати поданий педагогом матеріал, то весь процес навчання буде неефективним. Студент і викладач повинні взаємодіяти. Для цього педагог хоча б у загальних рисах зобов'язаний знати психологію того, кого він вчить.

3 цією метою пропонуємо викладачеві вузу монографію психолога В. Л. Зливкова “Професійна ідентичність та особистість педагога” [К., 2014. - 131 с.].

При розробці освітніх стандартів обов'язково враховуються можливості тих, хто навчається. У педагогічній літературі умовно визначено три типи студентів. До першого типу відносять тих, які відзначаються широким кругозором, мають чітку мету щодо навчання у вузі. Їх цікавить значно ширше коло професійних знань, ніж це передбачено навчальними програмами. Вони активні в 
науковій і громадській роботі. Такі студенти часом перебувають у стані творчого незадоволення результатами своєї праці, вони в постійних пошуках ефективних способів раціоналізації навчання. Уся їхня навчально-виховна робота повністю відповідає нормам і вимогам, які пред'являються до сучасного студента.

Студенти другого типу чітко зорієнтовані на вузьку спеціалізацію, їхня пізнавальна діяльність характеризується заглибленням у зміст саме професійної підготовки. У них нерідко спостерігається обмеження громадсько-культурних інтересів. Вони малоактивні в спорті, самодіяльності тощо.

Студенти третього типу пасивно ставляться до здобуття знань у рамках обов'язкової навчальної вузівської програми.

Цікаво, що при анкетуванні лише 3 \% від опитаних віднесли себе до першої групи студентів, до другої - всі останні, до третьої - жодний [1].

Педагоги і психологи вважають, що здібністю до творчості володіють не більше 5-10 \% від загальної кількості студентів, професіоналами стають близько 20 \% фахівців. Решта можуть у майбутньому стати непоганими виконавцями, але аж ніяк не генераторами ідей. Генії ж зустрічаються з частотою 1 на мільйон.

Європейський досвід переконливо доводить, що запорукою процвітання нації є її духовність, адже саме вона - висока і переконлива духовність формує Людину. Її відсутність породжує зневіру, що може привести до зростання злочинності, аморальності, ненависті, інших негативних для окремої людини і для суспільства в цілому рис.

Проблема духовності особливо гостро стоїть сьогодні, коли знищено старий виховний ідеал, відсутня парадигма виховання, орієнтація на нове сучасне мислення. Не випадково в більшості педагогічних публікацій трьох останніх років (2012 - 2014) йдеться про різні аспекти, пов’ язані не лише з навчанням, але й $з$ вихованням сучасних фахівців різного профілю.

\section{Список літератури}

1. Артемова Л. В. Педагогіка і методика вищої школи : навч. посіб. / Л. В. Артемова. - К., 2008. - 272 с.

2. Дидактичні технології викладання питань репродуктивного здоров'я : навч. посіб. для викладачів. - К., 2007. -656 c.

3. Комп’ютерно орієнтовані засоби та мультимедійні технології навчання : навч. посіб. - Вінниця, 2012. -619 с.

4. Мойсеюк Неля. Педагогіка : навч. посіб. для студентів вузів / Неля Мойсеюк. - К., 2007. - 656 с.
Враховуючи потребу України у відродженні духовності, усвідомленні своєї національної належності, навчальні заклади повинні забезпечити наповнення всіх ланок навчально-виховного процесу змістом християнської моралі та національної духовності, який би допомагав формувати свідомих українців. Вища школа зобов’ язана давати суспільству не лише спеціалістів високої кваліфікації, а й громадян високої моралі і культури.

Педагогічною наукою передбачено виховання таких якостей, необхідних для успішної професійної діяльності: ділових (працелюбність, дисциплінованість, обов'язковість), імпульсивно-вольових (емоційність, стриманість, тактовність, самокритичність), моральних (правдивість, скромність, справедливість, милосердя, почуття співчуття та ін.). Для фахівця-медика усе це передбачено клятвою Гіппократа.

3 нових педагогічних видань варто згадати й ті, що адресовані студентам і наставникам академічних груп. Серед них виділимо “Студент вузу: Технології навчання і професійної кар’єри” (навчальний посібник / за ред. проф. С. Д. Резніка. - М., 2011. - 475 с.). Тут знаходимо поради, як готувати себе до навчання у вузі, як домогтися, щоб час навчання у вищому навчальному закладі використовувати з максимальною користю, як раціонально працювати з літературою, як домогтися успіхів не лише в навчанні, а й у праці після вузу. По суті, автори ведуть студента від вступу до навчального закладу до його закінчення й успішного влаштування на роботу за професією.

Корисним для того, хто вчиться і хто вчить, буде ознайомлення з програмою “Крок за кроком”, розробленою викладачами університетів США за програмою фонду Д. Сороса, і виданим ними вузівським спецкурсом “Демократія в світі дорослих”.

Висновок. Засвоєння матеріалів вищеназваних педагогічних видань сприятиме підвищенню якості освіти й виховання у вузах України й наближатиме іiі до європейського рівня.

5. Нові технології навчання : наук.-метод. зб. № 67, ч. 1. - Вінниця ; К., 2012. - 208 с.

6. Нові технології навчання : наук.-метод. зб. № 67, ч. 2. - Вінниця ; К., 2012. - 221 с.

7. Нові технології навчання : наук.-метод. зб. - К. ; Вінниця, 2012. - 296 с.

8. Хоружій Г. Ф. Академічна культура: цінності та принципи вищої освіти : навч. посіб. / Г. Ф. Хоружій. K., 2012. - 320 c. 